\title{
回転円形水路における底泥の巻き上げに及ぼす 生物膜の影響に関する実験的検討 \\ EXPERIMENTAL STUDY ON THE EFFECT OF BIOFILM FOR BED MUD EROSION IN ANNULAR FLUME
}

\author{
渡辺亮一 ${ }^{1} \cdot$ 山崎惟義 $^{2} \cdot$ 楠田哲也 ${ }^{3}$ \\ Ryoichi WATANABE, Koreyoshi YAMASAKI and Tetsuya KUSUDA \\ ${ }^{1}$ 正会員 博 (工) 福岡大学講師 工学部 ( $7814-0180$ 福岡市城南区七隈 8- 19- 1) \\ 2 正会員 工博 福岡大学教授 工学部 ( \\ 3フェロー会員 工博 九州大学教授 大学院工学研究院 ( $=812-8581$ 福岡市東区箱崎 6- 10- 1)
}

\begin{abstract}
The prediction of fine cohesive sediment erosion is important information for civil engineers. However, to calculate an actual amount of erosion, the necessity for considering the effect by biofilm formed on the bed mud surface has been caused. Biofilm formed on the bed mud has a major influence on the erosion phenomenon in estuaries. Therefore, many researchers are grappling from various angles with this problem.

Experiments were carried out in an annular flume at the Water and Environmental System Laboratory of Fukuoka University. Results of an experimental study on the effect of biofilm for fine cohesive sediment erosion in the annular flume are described. The relation between biofilm on the bed mud and the initial rate of erosion were conducted under the condition to adjust the amount of light and water temperature. The thickness of biofilm reached about $2 \mathrm{~mm}$ in the maximum and $0.5 \mathrm{~mm}$ in the minimum. In this study, it has aimed to clarify how the amount of bed mud erosion changes by the biofilm experimentally
\end{abstract}

Key Words : bed mud, erosion, fine cohesive sediment, annular flume, diatomaceae, biofilm

1.はじめに

感潮域における微細な粒子からなる浮泥や底泥は 樣々な工学的な問題を引き起こしている．例えば， 港や内湾ではシルテーションにより航路が埋没し， 船舶の円滑な航行の妨げとなり，また，河川感潮域 では潮汐に伴って河川縦断方向に移動する水塊に高 濃度の懸濁物質が含まれており，河道断面上に沈積 した底泥は河川の洪水流下能力を低下させる．弚の ため，莫大なコストとエネルギーを費やして定期的 に浚渫工事を行う必要があり，掘削した航路が 1 年 で何 $\mathrm{cm}$ 埋没するか, 洪水でどのくらいの底泥が巻き 上げられるか等を定量的に把握することは工学的に 重要であると考えられる .

懸濁物質の沈降や底泥の巻き上け現象に関する研 究は以前から行われてきた. しかし, 微細粒子のも つ特異な性質のため, これまでの研究では底泥の巻 き上げ量とせん断強度の関係等の物理的側面の解明 に主眼がおかれる傾向にあった .たとえば，海田ら 1) は含水比の違いによって底泥の巻上げ形態, 巻き 上げ速度，限界せん断応力を整理している．これら の研究では実験当日または, 前日に水路に泥を敷き 詰め, 上層水を注入して 1 日静置または, 直ちに実
験を行うものが大半を占めていた .よって底泥の表 面に生物膜層が形成される間もなく実験が行われて いたと推察される.しかしながら, 実際の水域に堆 積する底泥の表層には生物膜層が形成されているの が一般的である.干潟の表面に形成される生物膜に はポリサッカライドを主とした非常に粘着性の強い 高分子物質が含まれていることが指摘されている． このように強い粘着性を示す生物膜層によって底泥 の巻き上げ現象にどのような影響が及ぼされている かを検証した研究はこれまでのところ行われていな い。

乥こで, 本研究では, 当研究室において作製した世 界最大規模の回転円形水路を用いて, 底泥表層部分 に形成される生物膜 (珪藻類) が底泥の巻き上げ量 にどの程度影響を与えているかを把握するために， 以下の二つの項目について明らかにすることを目的 として実験を行った。

(1)生物膜厚さや粘着性物質の到達厚さが巻き上げ量 に及ぼす影響

(2)生物膜層の形成過程に及ぼす光・水温・静置期間 の与える影響 


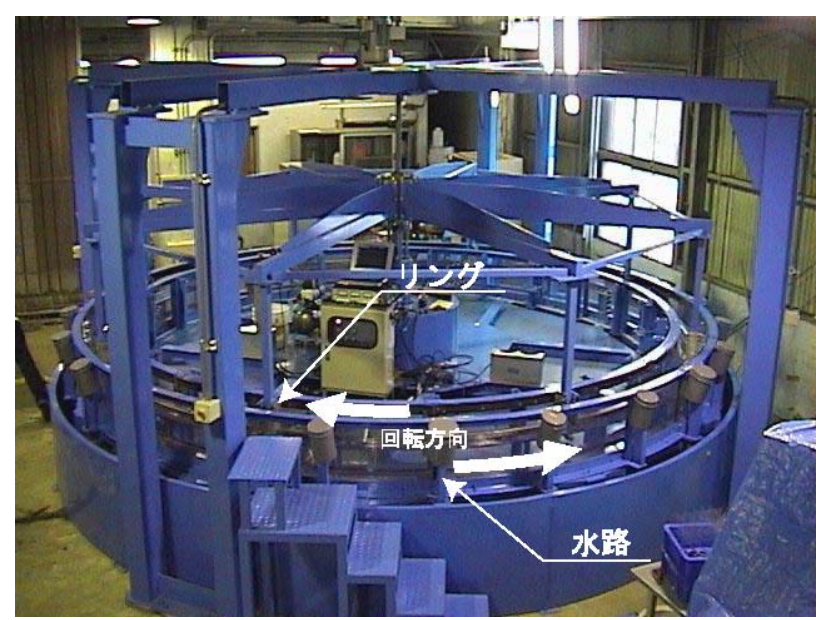

図 - 1 回転円形水路概観

\section{2. 実験に用いた装置について}

底泥の巻き上げ，沈降過程に関する研究に用いら れる代表的な実験装置として, 直線水路, 循環型直 線水路, 円形回転水路の3つがあげられる．底泥の ような凝集性微細粒子は, 粒径が非常に小さく砂粒 子と比べて, 沈降速度が遅く, 流送距離が長くなる ことから実験装置に特別な配慮が必要となる．仮に 直線水路を用いるとすれば, 直線水路には, 流入出 量の収支の問題 , 設置場所の問題を有する . また , 循 環型直線水路の場合，貯水槽を設け，ポンプを用い 循環させることで直線水路の欠点であった流入出量 の問題を解消したが，ポンプ内でフロックが破壊さ れてしまう欠点を有している，乥こで，直線水路，循 環型直線水路の欠点を解消することを目的として考 案された実験装置が回転円形水路である . 回転円形 水路は, 水路が円形であるため, 水路長が無限長と みなせる．また，流入出がないため水路断面内で現 象が一樣である .しかし，遠心力により2次流(らせ ん流) が発生する欠点を有しているため，リングと円 形水路を互いに逆方向に回転させ，2 次流の影響を 最小にする手法が用いられている。これまで研究に 用いられてきた円形回転水路の最大径は $2 \mathrm{~m}$ 程度 ${ }^{2)}$ で あり，2 次流の影響を無視し得る条件を設定すると， 水路底面で発生させることが可能なせん断応力が小 さくなるという欠点を有していた，乥こで，本研究 室では，これまで設定することができなかった条件 で実験可能な世界最大規模の回転円形水路 $(5 \mathrm{~m}$ : 図 1参照)を作製し，乥の水路特性を把握するための実 験を行った 。

図 - 1 および図 - 2 は, 実験に用いた内径 $4.6 \mathrm{~m}$, 外 径 $5 \mathrm{~m}$, 深さ $0.4 \mathrm{~m}$, 水路幅 $0.2 \mathrm{~m}$ の回転円形水路の概 略を示している.円形水路，リングは，ともに透明 の塩ビ製の板を使用し，光の透過を妨げないように 配慮している. 円形水路は回転円板上に固定し，リ

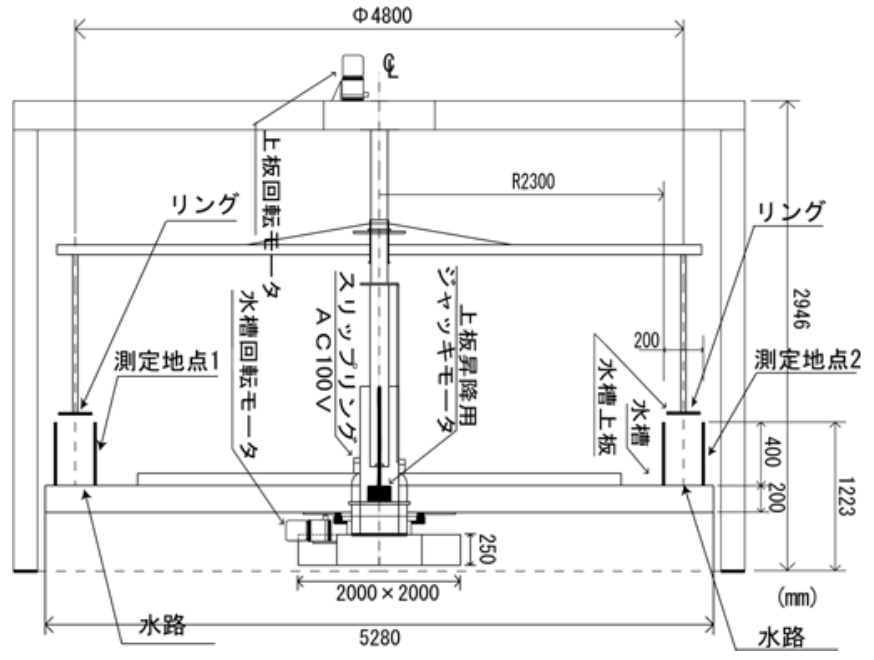

図 - 2 回転円形水路断面図

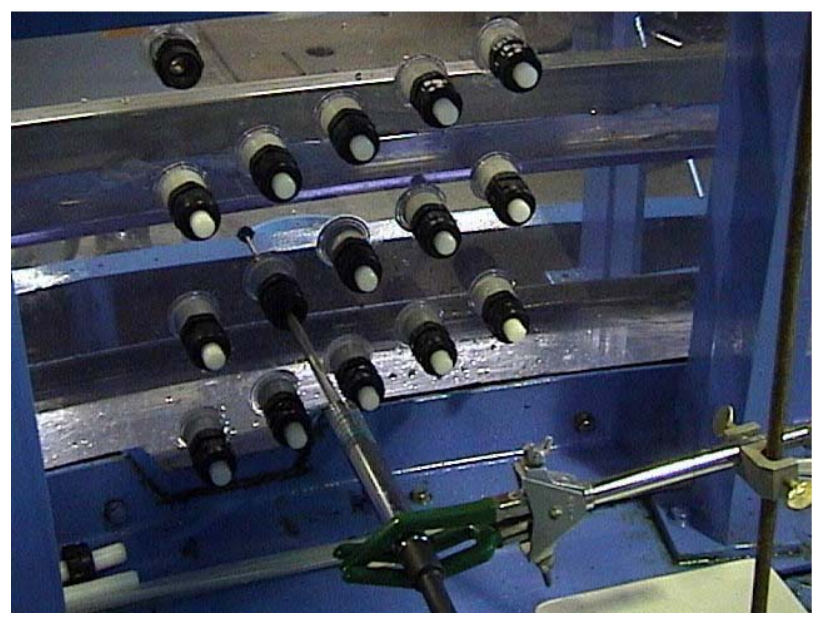

図 - 3 流速測定地点概要

ングはアームの先端に固定した . 円形水路 , アーム は, ともにモーター, 回転速度制御装置を有し, 中 央の 2 重回転軸を通じて独立で回転できるように なっている．また，リングは，昇降機能を有してお り，水深を自在に変化できる機構を有している．

水路内の 2 次流の影響を明らかにし, 装置の操作 曲線を作成するために，予備実験として水路内の流 速分布を測定した. 円形水路に水道水を入れ，所定 の水深となるようにし，リングが水面に接するよう にセットした．また，水路の内側に測定地点を2ヶ所 対角線上に設け，測定地点 1 , 測定地点 2 とした . 測 定地点は，底面から $2 \mathrm{~cm}$ 間隔の流速計差込み口を設 け， 3 次元電磁流速計 (先端部球形 $\varphi$ 13mm) を差し 込み, 半径方向に1cmずつ計19ヶ所の測定点におけ る流速を測定した . (図-3参照)

図-4および図-5は,リングと円形水路を互いに逆 方向に回転させたときの 2 次流分布と主流方向流速 分布を示している . 縦軸を水深 $(\mathrm{cm})$ ，横軸を回転円 形水路の中心からの距離 $(\mathrm{cm})$ としている . これらの 


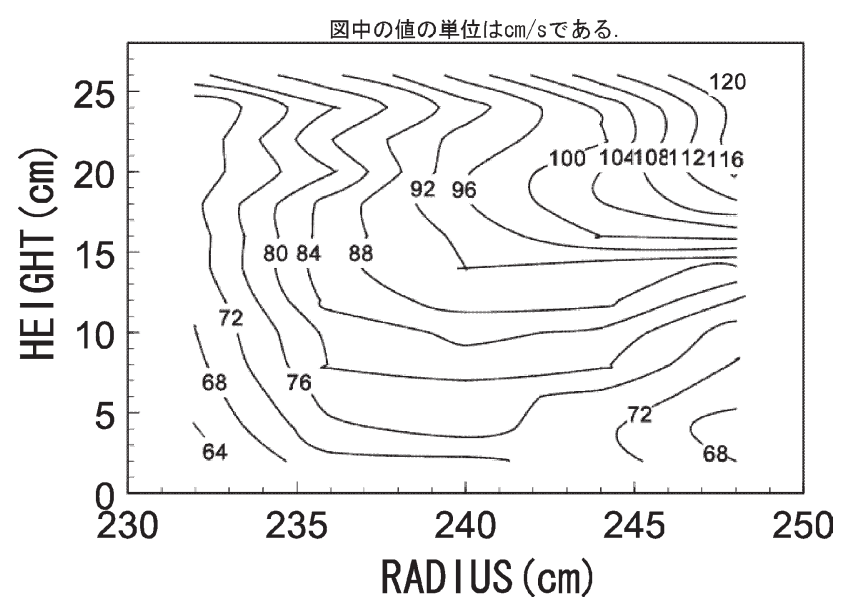

図-4 水路内の主流方向流速分

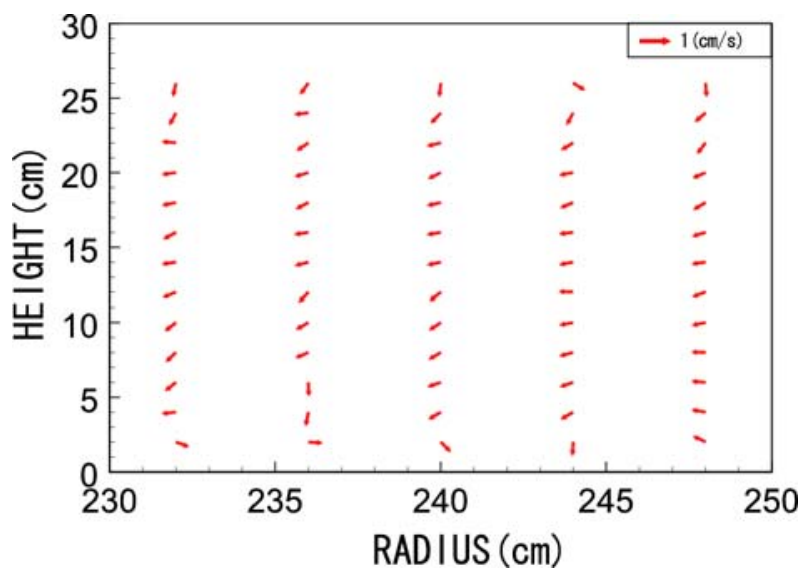

図 - 5 水路内の 2 次流分布

図より,リングと円形水路を互いに逆方向に回転さ せることで，水路断面内で 2 次流が $1 \mathrm{~cm} / \mathrm{s}$ 以下とな り，底面付近ではもちろん，水路断面全体において も2 次流を最小にすることができた．また，図-4に 示されているように, 主流方向の流速が底泥の巻き 上げ現象に最も影響を与える水路底部にて，直線水 路と同等の流れを再現できている，すなわち遠心力 の影響が極力抑えられ，一方向流下での巻き上げ現 象を再現できていると考えられる .

図 - 6 は各回転数でリングと円形水路を互いに逆方 向に回転させた時の水路中央部( $R=2.4 m)$ における主 流方向流速分布を鉛直方向にプロットしたものであ る. 縦軸を水深 $(\mathrm{cm})$, 横軸を主流方向流速 $(\mathrm{cm} / \mathrm{s})$ と している .この図から，水路中央部での鉛直方向流 速分布形状より, リング部下面と水路底面部付近に おいてのみせん断応力が発生しているものと見なす ことが出来るものとした . 底面せん断応力を求める 方法としては, リングのせん断応力と水路の諸面積 より算出する方法が一般的であるが，今回リング部 のせん断応力が実測できなったため, 式(1)に示す Pr andt I の運動量輸送の理論を用いて推測した . 今 後, 何らかの手法を用いてせん断応力を実測する必

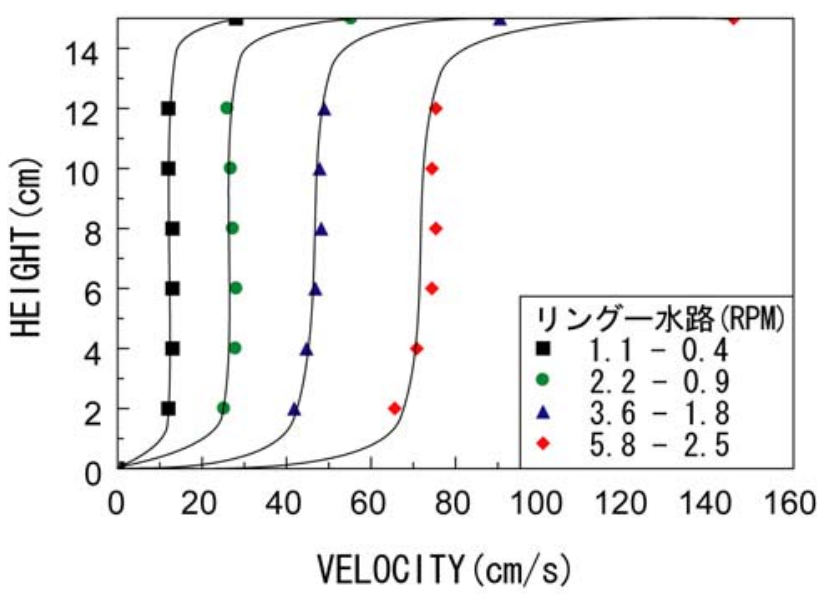

図-6 水路内鉛直方向流速分布

要があると考えられる .

$$
\frac{\tau}{\rho}=(\varepsilon+v)\left|\frac{d \bar{u}}{d y}\right| \quad, \varepsilon=l^{2}\left|\frac{d \bar{u}}{d y}\right| \quad, l=\kappa y
$$

ただし，T：底面せん断応力， $\epsilon$ : 渦動粘性係 数, $v$ : 動粘性係数, $\rho$ : 水の密度, I: 混合距 離, $\mathrm{K}$ ：カルマン係数 $(\mathrm{K}=0.4)$, また,$\epsilon \gg \mathrm{V}$ よ り，分子粘性の影響は無視できるものとした 。

\section{3．実験手法および条件}

\section{（1）実験に用いた試料}

本実験に用いた試料は，佐賀県の六角川で採取し た. 試料の物性值は, 真密度 $2640 \mathrm{~kg} / \mathrm{mp}^{\mathrm{p}}$, 強熱減量 $18 \%$, 中央粒径 $1.4 \mu \mathrm{m}$ であり，粒度組成は粘土分約 $78 \%$, シルト分約 22\%で地盤工学での三角座標分類で は粘土に属している．実験に用いた試料懸濁液は密 度 $1025 \mathrm{~kg} / \mathrm{m}^{3}$ の塩水て調整し, 水路内のSS 濃度か約 $20 \mathrm{~kg} / \mathrm{m}^{\beta}$ となるように調整した 。

\section{（2）水路内の濃度測定}

底泥からの巻き上げ量は, 水路内の濃度分布を測 定することによって算出した．採水装置は外径 $2 \mathrm{~mm}$ のステンレス製パイプでできており，水路内に自由 に挿入すことが可能である . 採水位置は水路内壁 より 4cm程度離れた所で行った . 図-7にSS濃度の測 定点を示す.サンプリングは 19箇所の測定点で同時 刻に行っている. また, 濃度の測定には吸光度計を 用いた . 予め, 所定の濃度 (実験時に予想されるSS 濃度) に調整した試料懸濁液 (10検体) の吸光度を 測定した後, この試料をメンブランフィルターで濾 過し, 乾燥後秤量することて吸光度とSS濃度のキャ リブレーションを行った . 実験時の底泥の巻き上げ 量は, 水路内のSS濃度を経時的に測定することによ り，弚の時間の変化分を求めることにより算定した . 


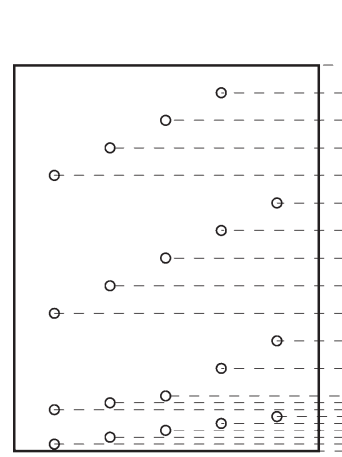

側面図

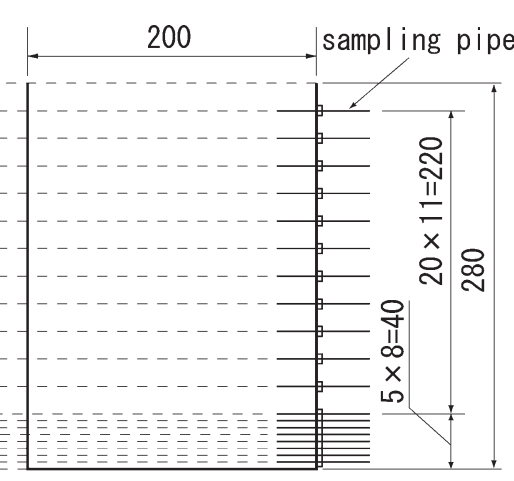

断面図

(unit:mm)

図 - 7 水路内の SS 濃度測定地点概略

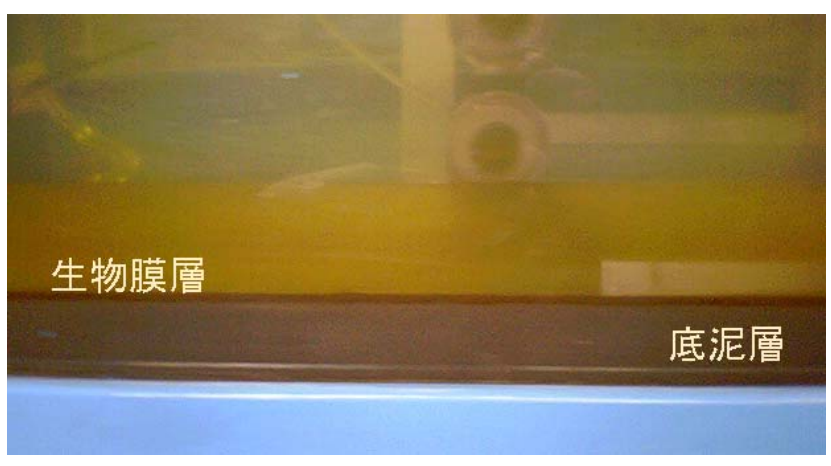

図 - 8 実験開始時の生物膜の樣子

\section{（3）生物膜の形成方法}

水路に試料懸濁液を水深 $28 \mathrm{~cm}$ となるように注入し 自然沈降させた後, 所定の期間静置し生物膜層を形 成させ，実験を行った．また，水路内の光の照射条 件として明条件と暗条件を設定した . 明条件では実 験期間を通して，水路内に 24 時間，水銀灯で光を照 射し続けた．暗条件では，実験期間を通して，黑の ビニール袋で水路を覆い, 光が底泥表面に照射する のを抑えた .

表 - 1 に示す静置期間経過後, 水路内の対角線上に 取った四箇所で生物膜層の厚さを $\mathrm{PC}$ モニター上で読 み取り，弚の厚さを測定した。図-8は，明条件下で 14 日静置した後の底泥表層をあらわしている .この 図から，表層に数ミリの生物膜層が形成されている ことがわかる .

\section{（4）実験条件}

表 - 1 は実験条件を示している. 水路内に注入した 懸濁液の濃度は約 $20 \mathrm{~kg} ・ \mathrm{mp}$ となるように調整し，注 入後所定の期間静置する. 静置している期間に光を 照射する条件を明条件，この期間に黑のビニール シートで水路に覆いをして光を遮る条件を暗条件と した . また，回転円形水路は温度調節機能のない場 所に設置してあるため, 全ての実験は室温下で行っ

表 - 1 実験条件

\begin{tabular}{|c|c|c|c|c|c|}
\hline & 初期德度 (g/1 & 静置条件 & 静置期間(日) & 水沮 $\left({ }^{\circ} \mathrm{C}\right)$ & 生物膜層 (m) \\
\hline RUN1 & 20.0 & 明 & 19 & 32.8 & 1.9 \\
\hline RIN2 & 21.6 & 暗 & 7 & 28.9 & 0.7 \\
\hline RINB & 19.1 & 明 & 7 & 22.2 & $\overline{1.6}$ \\
\hline RINA & 20.3 & 暗 & 7 & 19.4 & 0.5 \\
\hline RINI5 & 23.4 & 明 & 14 & 17.9 & 1.0 \\
\hline RIN6 & 21.5 & 暗 & 14 & 14.9 & 0.6 \\
\hline
\end{tabular}

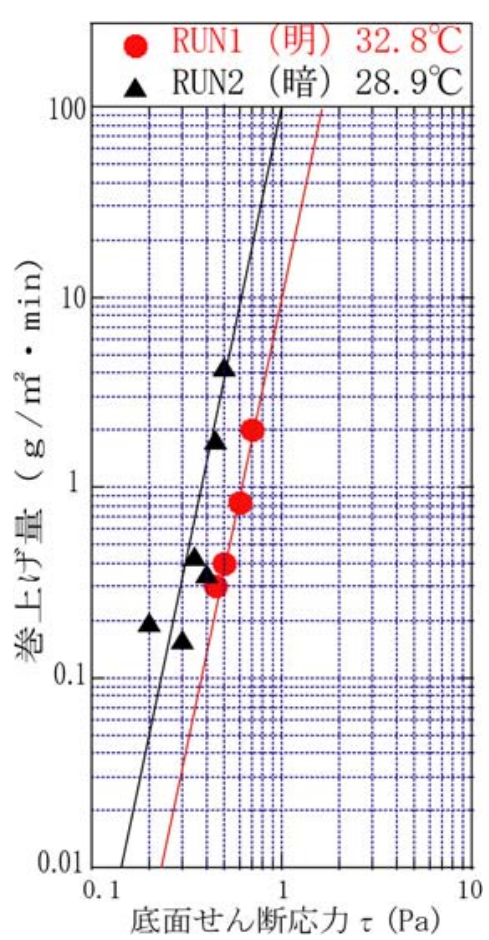

図 - 9 高水温域での底面せん断応力と巻き上げ量の関係 (RUN1 と RUN2の比較)

た.表-1中のRUN1 と 2は比較的高水温域 (約 $30^{\circ} \mathrm{C}$ )， RUN3 と 4 は中水温度域 (約 $20^{\circ} \mathrm{C}$ )，RUN5 と 6 は低水 温域 (約 $16^{\circ} \mathrm{C}$ ) での現象を再現しているものとして いる。

\section{4. 実験結果}

\section{(1) 高水温域での実験結果（RUN1 と 2の比較）}

図-9は，RUN1 とRUN2におけるせん断応力と巻き 上げ量の関係を示している。この時, 生物膜層は明 条件 (RUN1) で1.9 mm, 暗条件 (RUN2) で0.7 mmほ ど形成されていた。この図から，明条件 (RUN1) と 暗条件 (RUN2) では1オーダー近く暗条件の巻き上 げ量の方が大きくなっていることがわかる．このこ とから, 生物膜が厚く底泥表層を覆っている時の方 が巻き上がりにくくなっていると考えられる．また， 巻き上げ限界底面せん断応力は, 明条件 (RUN1) で 0. 45Pa，暗条件 (RUN2) で0.2Paであった . 


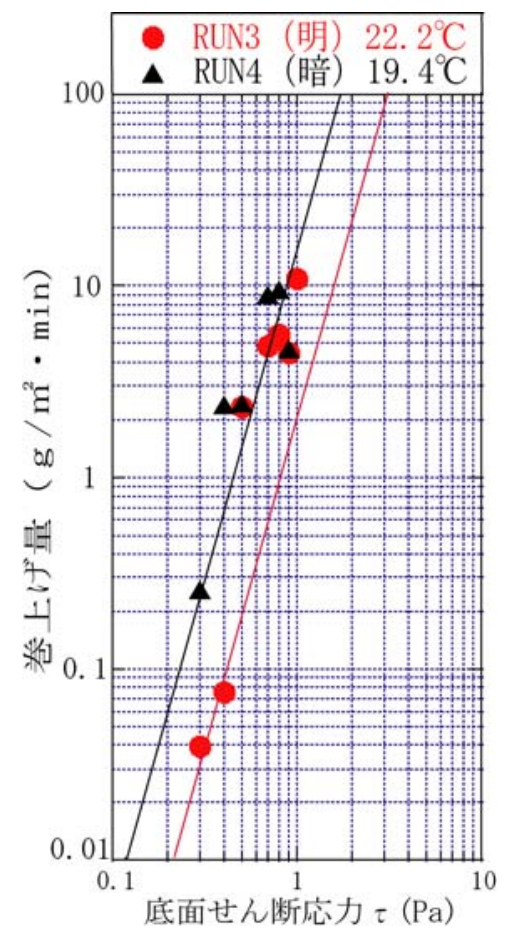

図 - 10 中水温域での底面せん断応力と巻き上げ量の関係 (RUN3 と RUN4の比較)

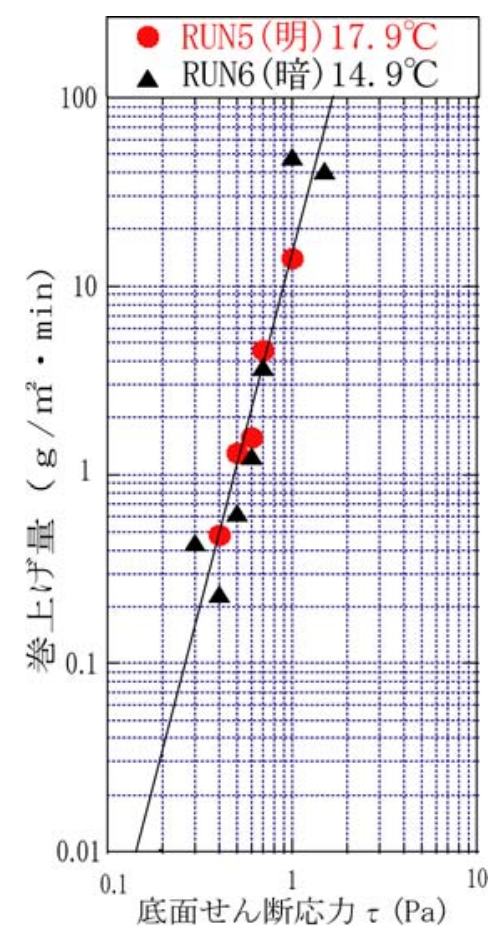

図 - 11 低水温域での底面せん断応力と巻き上げ量の関係 (RUN5 と RUN6 の比較)

（2）中水温域での実験結果( RUNBと 4の比較)

図 - 10は, RUN3 と4 におけるせん断応力と巻き上 げ量の関係を示している .この時, 生物膜層は明条 件 (RUNB) $1.6 \mathrm{~mm}$, 暗条件 (RUN4) $0.5 \mathrm{~mm}$ ほど形成さ れていた .この図から, 明条件 (RUN3) で底面せん 断応力 $0.4 \mathrm{~Pa}$ までは, 巻き上げ量の低下がみられた .

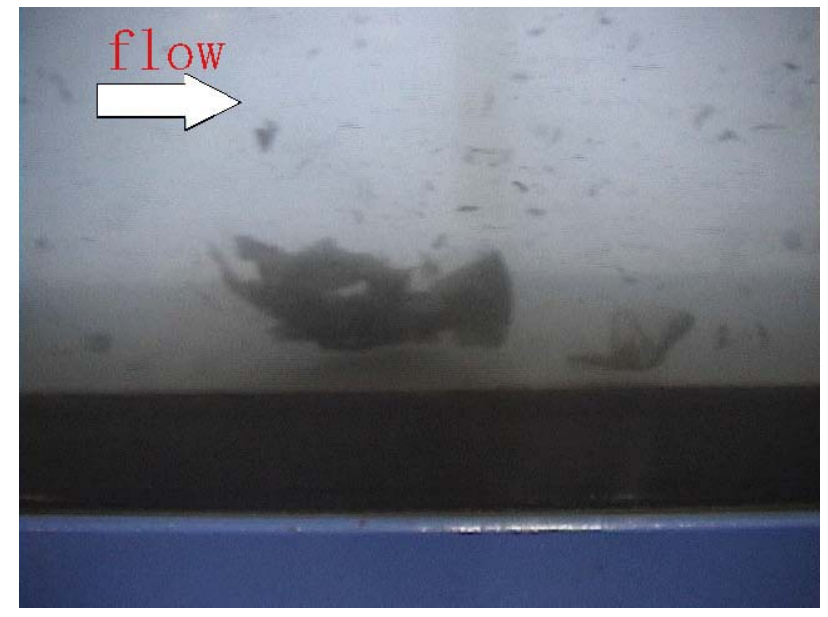

図-12 明条件下での巻き上げ初期の樣子

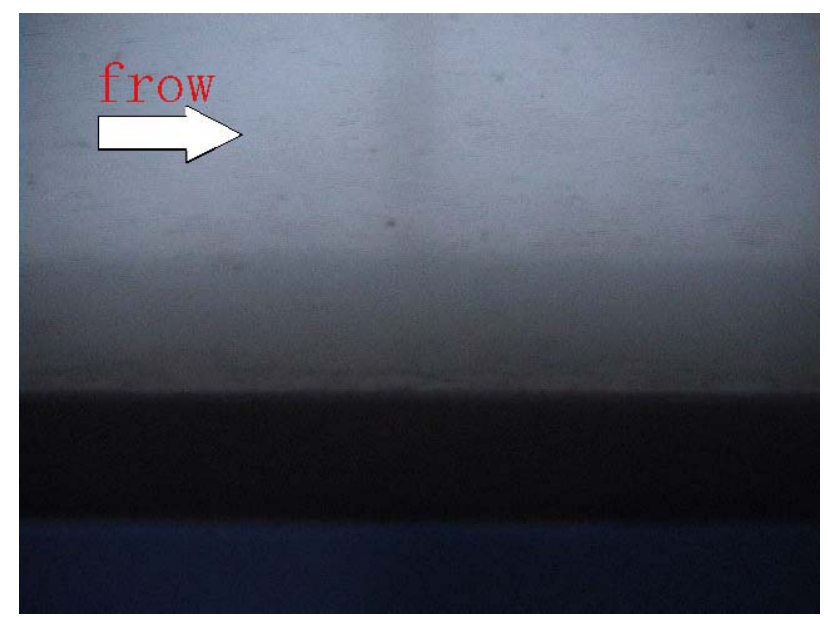

図 - 13 暗条件下での巻き上げ初期の樣子

しかし, せん断応力を $0.4 \mathrm{~Pa}$ 以上にすると巻上げ量 が増え，暗条件の場合の巻き上げ量との間に差違が 見られなくなった . また, 巻き上げ限界底面せん断 応力は, 明条件 (RUNB) で0.3Pa, 暗条件 (RUNA) で 0.3Paであった .

\section{（3）低水温域での実験結果（RUN5と 6の比較）}

図 - 11 は, RUN5 と 6 におけるせん断応力と巻き上 げ量の関係を示している. 明条件 (RUN5) の生物膜 層は今回の実験を通じて最も薄く $1.0 \mathrm{~mm}$ であった . この図から，明条件 (RUN5) と暗条件 (RUN6) に巻 き上げ量の違いは表われなかったことが分かる . こ れは実験開始直後に明条件下 (RUN5) で形成された 生物膜層が巻き上がってしまったからであると考え られる . この時の巻き上げ限界底面せん断応力は明 条件 (RUN5) で0.4Pa, 暗条件 (RUN6) で0.3Paで あった .

\section{5. 実験結果の考察}

図 - 12 は, 明条件下の実験での巻き上げ初期の樣 


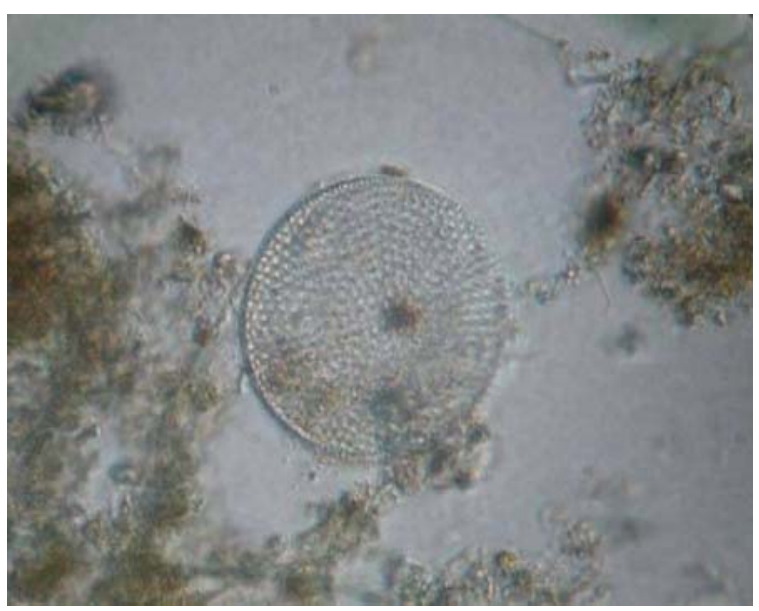

図 - 14 巻き上がった生物膜の顕微鏡写真 (珪藻類 : Thal assi osi ra)

子を表している .この図中で, 膜のようにして巻き 上がっているのが生物膜の表層部分である . 実験中， 巻き上げに関する限界せん断応力に達すると生物膜 がこのようにして巻き上がった . 次に, 図-13は, 暗 条件下での巻き上げ初期の樣子を示している．PC モ ニター上の観測結果から, 暗条件下でも表層に生物 膜は形成されているものの, 明条件下での樣な膜状 の厚い層は形成されていないことがわかった . また， 図－14は，実験時に巻き上がった生物膜を実験終了 後, 実体顕微鏡で撮影した写真である.このように， 巻き上がった生物膜の多くは珪藻類を中心とした藻 類とバクテリアによって構成されていると考えられ る. 珪藻類の中でも Thal assi osi r a は自身の周辺を 粘着性の非常に強い細胞外ポリマーで覆い, 底泥表 層に固着していること, また他の藻類やバクテリア も高分子で粘着性の強い物質を放出することが知ら れている3).

このため，表層に形成された生物膜の影響は，表 面部だけでなくある程度の深さまで影響を及ぼして いると考えられる .この影響が最もよく表れている のが，図-10に示した中水温域での実験結果である . この図から，実験開始から徐々に剥がれて来た粘着 性の強い生物膜層が $0.4 \mathrm{~Pa}$ の段階で無くなったため であると考えられる . ただし, 生物膜の到達深さに 関しては, 分析方法等を考案して定量的に把握して いく必要性があると考えられる.

次に, 生物膜層の厚さに関しては, 厚さが約 $1 \mathrm{~mm}$ 以 上形成されたときには, 底泥の巻き上げ量が1オー ダ一程度低下することが明らかになった．また，水 温が低くなるにつれ, 珪藻類やバクテリアの活性が 落ちるため, 形成される膜の厚さも薄くなると同時 に, 粘着性物質の到達深さも浅くなったと考えられ る，このため，図-11に示されるように，低水温時 の実験では光の照射条件の違いによる巻き上げ量の 差異が見られなくなった .

\section{6. 結論}

（1）生物膜厚さや粘着性物質の到達厚さが巻き上げ 量に及ぼす影響

今回の実験結果より，底泥表層に生物膜の厚さが 約 $1 \mathrm{~mm}$ 以上形成された場合には，底泥の巻き上げ量 が生物膜の厚さが $1 \mathrm{~mm}$ 未満の場合よりも約 1 オー ダ一程度低下することが明らかとなった．また，底 泥表層の生物膜層および粘着性物質の到達している 層が巻き上げられた後の巻き上げ量は, 生物膜の厚 さが $1 \mathrm{~mm}$ 未満の場合の巻き上げ量とほぼ同程度にな ることがわかった .

（2）生物膜層の形成過程に及ぼす光·水温·静置期 間の与える影響

底泥表層に形成される生物膜層の厚さは, 水路内 の水温が約 $20^{\circ} \mathrm{C}$ 以上の場合には, 光を照射させた条 件の方が厚く形成されることがわかった . 特に, 中 ・ 高水温域では, 弚の差が顕著に現れた。しかしなが ら，水路内の水温が $16^{\circ} \mathrm{C}$ 程度に低下すると生物の活 性が落ちはじめるために, 形成される生物膜の厚さ の差は顕著に見られなかった . また, 生物膜層の形 成に及ぼす静置期間の影響に関しても，光の照射条 件よりも水温による影響が大きいことがわかった .

これらのことから推察すると，感潮域においては， 夏場は底泥が巻き上がり難い状態となり, 冬場は比 較的巻き上がり易い状態になっていると考えられる． 今後, 現地の観測データと比較検討してみる必要が あると考えられる .

謝辞: 本研究の一部は, (財) 前田記念工学振興財団 の助成により行われている.ここに記して謝意を表 する．また，本実験を遂行するに当って昼夜を問わ ず観測を行ってくれた福岡大学大学院の諸氏に深く 感謝いたします。

\section{参考文献}

1) 海田輝之, 楠田哲也, 粟原陽一: 柔らかい底泥の巻上げ 過程に関する研究, 土木学会論文集,第393号/ II -9,pp33pp37, 1988.

2)二渡了: 円形回転水路と产の流況特性, 九州大学工学集 報，第 57 巻，第 4 号, 1984 .

3) Prochnow, J, Schweim C. and Koengeter, J.: Simulation of biogenic sediment stabilization by heterotrophic bacteria in an annular flume, Proceedings in Marine Science, Vol.5, in Fine Sediment Dynamics in the Marine Enviroment, ELSEVIER, pp.393-407, 2002.

( 2005. 9. 30 受付) 